\title{
University Students and Online Social Networks: Effects and Typology
}

\begin{abstract}
:
Immersed, educated, and raised amid technology, the new student generation is formed by digital natives. The use of online social networks (OSNs) has soared in recent years, and students are among those who have adopted them more enthusiastically. Therefore, it is necessary to analyze how students' academic life is shaped by the use of such networks. After providing a review of the literature on OSNs and their influence on students, this study presents the results of a survey that proved helpful to assess students' opinions in this regard. A typology of students based on their perceptions of OSNs is provided. The findings suggest that students value the positive aspects of OSNs to a much greater extent than they value the negative aspects of OSNs.
\end{abstract}

\section{Keywords:}

Online social networks, Universities, students, academic performance, survey 


\section{Introduction}

Skills related to collaboration and teamwork undoubtedly stand out for their relevance in current as well as future organizations. Both the firms and the academic institutions which deal with students' competences stress that learners should be increasingly able to work not only inside teams but also collaboratively, and in an autonomous way (Helm, 2017). Online social networks (OSNs) actually serve such purposes.

Teachers are responsible for transforming a technology usually seen as a distraction into a learning tool that can: promote problem solving; make the use of information sources easier; improve collaboration; permit the interaction of students with one another as well as with teachers and experts; and help improve students' integration into education centers, thus improving their academic performance too (Siegle, 2011; Evans et al., 2016).

However, a number of recent reports have revealed that the obsession with OSNs, which reaches levels above other common addictions such as tobacco (Aladwani \& Almarzouq, 2016), may mean a waste of time by the multiple distractions involved. Furthermore, despite all the existing research on the use of Information Technologies as a teaching tool, a better understanding still needs to be acquired about how to exploit them for the creation of collaborative spaces meant to promote deep, long-lasting learning (Magen-Nagar \& Shonfeld, 2018). This shows the importance of examining not only the possible problems but also the potential benefits that using OSNs brings to university students. For that purpose, the present research work took advantage of students' opinions to try to identify the strengths and weaknesses of OSNs as well as their impact on academic performance. With this aim in mind, the literature review is followed by the presentation of the results obtained during a survey carried out among undergraduate students enrolled in subjects related to Human Resource Management. It was additionally being sought to establish a typology of students according to their attitude toward OSNs, and the influence that the latter may have on their studies. 
Establishing a typology will prove useful for lecturers; if they understand that not all students behave in the same way when it comes to OSNs, that will help develop a variety of action patterns aimed at different student profiles.

\section{Literature review}

\section{INSERT TABLE 1}

Social networks are communities of people who share some type of interest. The Internet as well as Web 2.0 and 3.0 technologies do nothing but amplify social networks. According to Gneiser et al. (2012), OSNs allow individuals: (a) to build a public or semi-public profile within a well-defined system, (a) to articulate a list of users with whom they have a connection and, finally, (c) to see and cross their connections list with others made by different individuals belonging to the same system.

Albeit extensive, the literature on OSNs and their influence on students is actually recent. A short review of these publications along with their main conclusions can be found in Table 1 . As shown therein, numerous works suggest that using OSNs positively influences students' performance. Nevertheless, other research studies warn about potential negative effects. The review of the works listed in Table 1, and especially those authored by Gonzalez Gasco and Llopis $(2015,2016)$, shows the main specific strengths and weaknesses of these networks in the context of university studies, namely: time, addiction, attention deficit, anxiety, privacy, and multitasking; as for strengths, collaboration, friendship, trust, motivation, and commitment stand out.

\subsection{OSN Weaknesses}

Time, addiction and attention deficit. One of the most important problems generated by social networks is the time spent on them, together with the fact that they can eventually create an addiction. Students become dependent on them, with a possible reduction in the level of 
attention devoted to studies (Berger, Wyss \& Knoch, 2018). Some students are unable to impose strict limits on themselves in terms of time consumption (Paul et al., 2012). Because networks are so easy to use, and since one can upload posts or videos — among other things — so quickly and easily, an evident risk exists of saturating both the system and the students themselves with information, which forces them to manage this information overload (Duncan \& Barzyk, 2013). In addition to information that may prove useful to students, these networks contain a whole series of distractions which are true "time thieves" - e.g. advertisements, suggestions, and games, to quote but a few - and can ultimately trigger an addiction (Zaremohzzabierh et al., 2014). The time spent on OSNs is closely linked to addiction and attention deficit, which results in a growing inability to concentrate among students, who consequently have more difficulties to continue their studies normally (Paul et al, 2012).

Anxiety. A more frequent use of OSNs significantly correlates with students' anxiety (Lee, 2014). Nevertheless, it is necessary to analyze in more depth whether more anxious students use OSNs to a greater extent or whether it is actually OSN use that increases their anxiety. In any case, it does seem clear that many students obsessed with networks show signs of anxiety when they cannot consult their networks and check the information from their contacts for a long period of time. This state of anxiety becomes very visible, for instance, when a student is unable to use the mobile phone with which he/she usually accesses their social network accounts. As highlighted by Mendoza et al. (2018), being unable to communicate with others, losing the connection or being prevented from access to information fills youngsters with anxiety -aggravated if they cannot $\log$ on to the Internet for about 10 minutes. Curiously enough, 10 minutes is the time after which attention begins to decline when studying.

Privacy. Sharing ideas or information on OSNs is impossible unless you previously achieve other people's contacts or "befriend" them. However, students may be distrustful about teachers asking them for contact on OSNs (Taylor, Mulligan \& Ishida, 2012; Lampe et al., 2011). Due 
to reasons associated with privacy, many teachers and students choose to keep separate OSN accounts for personal and academic issues. Other students are simply reluctant, and thus refuse to use OSNs seeking to preserve their privacy (Hew, 2011).

Multitasking. Students like doing several tasks at the same time, e.g. studying and checking their networks. Young people seem able to simultaneously perform different tasks without losing efficiency and effectiveness, as if an evolution had taken place in their brain with respect to previous generations (Lee, 2014). However, numerous studies suggest that multitasking is impossible: the brain cannot perform two tasks at the same time (Kirschner \& Karpinski, 2010). Trying to do several things simultaneously has negative effects on academic results (Judd, 2014; Junco 2012b) because it implies an information overload for students which prevents them from accomplishing a calm, deep learning.

\subsection{OSN Strengths}

Collaboration. If OSNs can prove useful in one area, that is undoubtedly information exchange, which in turn constitutes the basic type of collaboration (Wang, 2013). Networks allow learners to organize themselves during an academic year, reducing the costs of communication with other students (Lampe et al., 2011). This informal nature fits in very well with the interaction habits of students, who have found a channel to reach their friends in these networks and adopt them as a tool for collaborative work (Suwannatthachote \& Tantrarungroj, 2012).

Friendship, trust. Students utilize social networks as a means to maintain and reinforce friendship ties with people outside their studies or with their own classmates (Kalpidou et al., 2011). Trust between students increases mutual collaboration. Students who trust their classmates to a greater extent are more likely to learn from them than when trust levels are low (Chang \& Lee, 2013; Rouis, Limayen \& Salehi-Sangari, 2011).

Motivation and commitment. From an academic point of view, using OSNs improves not only the motivation to learn but also the learning climate inside classrooms, since it creates new 
relationships between students and teachers, or between students themselves (Wang, 2013). Cain \& Policastri (2011) highlighted that subjects become more interesting or motivating because social networks allow students to see the direct testimony of experts, in posts or videos, which ultimately improves the appeal of subjects. "Commitment" is understood here as the amount of physical and mental energy that students dedicate to their academic experience. In this sense, a variety of works concluded that using OSNs as a teaching —or learning — tool is likely to improve students' commitment level (Al-Rahmi, Othman \& Musa, 2014; Jaffar, 2014; Kaur, Ganapathy \& Sidhu, 2012).

\section{Methodology}

The survey prepared included not only the interviewee's profile data but also some reflections on the possible strengths and weaknesses of social networks for teaching and learning.

The students to which this survey was addressed where those enrolled in the subject Human Resource Management — taught at the degrees of Business and Labor Relations at the University of Alicante (Spain)— during the 2016/17 academic year.

As for the study technical specifications, 84 (56.3\%) out of the 149 students enrolled in the two aforementioned subjects gave valid answers (population: 149 students, sample size: 84 answers - 55 students failed to answer the survey questionnaire because they did not attend class on the day when it was administered). These results revealed a low sampling error considered acceptable for their significance (7.09\%). The interview was carried out in paper format during the last weeks of the academic year (May 2017).

The two variables concerning the strengths and weaknesses of OSNs as well as their impact on students, on learning, and on teaching in general, came from a thorough review of the literature about this topic, and especially from Gonzalez, Gasco \& Llopis (2015). The construct about OSN Weaknesses had 12 items, and its reliability was acceptable/good (Cronbach's equals 
0.797), whereas that about OSN Strengths had 11 items, its reliability being good (Cronbach's equals 0.803 ). These constructs were measured using a 1-to-5 Likert-type scale (Table 2). A set of statements was proposed in the construct related to the Strengths and Weaknesses of online social networks in relation to students' performance, and students had to assess the extent to which they disagreed or agreed with them using scores from 1 and 5. These statements will be subsequently assessed in the results section —and collected in Table 4.

\section{INSERT TABLE 2}

\section{Results}

\subsection{Descriptive analysis}

The profile of the interviewed students, along with the networks that they use, can be found in Table 3. It becomes visible that female sex prevails; and also that interviewees are 22.9 years old on average, to which must be added that any student uses an average of 3.6 social networks. They were asked to specify their social networks, Facebook, followed by YouTube and Instagram, standing out as their favorites.

\section{INSERT TABLE 3}

As for Table 4, it shows the score given to the items referring to OSN weaknesses and strengths in connection with academic performance. Special emphasis needs to be placed on some problems generated by OSNs, including the reduction of students' capacity to concentrate (mean 4.243) and the negative impact on the time and attention dedicated to studies (mean 3.825 and 3.456). The least valued items have to do with (a) anxiety problems derived from being unable to use social networks (mean 1.662), and from being unaware of all the information uploaded to those networks (mean 1.831); and with (b) privacy-related problems (mean 2.271). 
Similarly, Table 4 shows the items associated with OSNs strengths and their connection with students. It follows from the analysis of this table: that networks turn out to be especially helpful in teamwork contexts (4.095); that students like their partners to communicate with them by means of OSNs (3.928); that network use can improve the degree of satisfaction with studies (3.702); and, finally, that networks largely help students in terms of content sharing (3.702). The least valued item, well below the mean, refers to the use of OSNs with classmates as a means to help remind them of the need to go back to study (2.839).

\section{INSERT TABLE 4}

The comparison of scores given to OSN weaknesses and strengths with their mean, median and mode values leads to state that, on the whole, students value items related to strengths to a greater extent than they value items related to weaknesses.

\subsection{Typology: Factor Analysis}

A factor analysis from items related to OSN strengths and weaknesses was carried out next. Its aim consisted in reducing those items to a lower number of variables — known as factorswhich gathered all the common characteristics underlying several items (Hu, 2006). With this aim in mind, the pertinence of such an analysis was firstly checked. It seemed advisable to undertake a factor analysis, insofar as the correlation matrix determinant was close to zero, the Kaiser-Meyer-Olkin index lay between 0 and 1 and above 0.5, and Bartlett's Sphericity Test was significant (Bartlett, 1950) (Kaiser-Meyer-Olkin Index: 0.595, Bartlett's Sphericity test: 659.639, significance: 0.000$)$.

\section{INSERT TABLE 5}

The implementation of Principal Components Analysis revealed 7 Eigenvalues above 1, which suggested, according to Kaiser's criterion, the convenience of extracting seven factors which explain $71.5 \%$ of the information supplied by the original variables (a satisfactory ratio, since 
it exceeds 50\%). Seeking to better interpret these factors, a Varimax rotation was performed. Table 5 shows the resulting factors together with the original items involved in their formation. The first factor, termed as Time, addiction, and attention deficit, brings together several items linked to negative influences of OSNs on studies, such as taking time away from study and, therefore, causing students to waste their time. In short, students need to control themselves to avoid overusing these networks, which can turn them into addicts, and accordingly reduce the degree of concentration and attention in their studies. This first factor stands out as the most important one, accounting for $19 \%$ of the variance explained in this analysis. It is followed by three factors which reflect positive features or strengths of OSNs, though.

The second factor, which explains $11 \%$ of the information contained in this analysis, was labelled as Collaboration because it refers to the capacity for OSNs to improve inter-student collaboration, to support group work, and to share contents, all of which favors greater satisfaction levels in studies, helped by the possibility to socialize with both classmates and teachers.

The third factor -Friendship and trust - explains $10 \%$ of the information generated in this factor analysis. The items shaping it refer to students' preference for their classmates or teachers to communicate with them using OSNs, to how these networks help them strengthen their friendship, and to feel more integrated into the group of partners belonging to that network, and even to the greater trust placed on those classmates with whom they most often interact on OSNs.

The fourth factor has to do with Motivation and commitment, and it explains $9.8 \%$ of total variance in this analysis. This factor comprises items showing that, when partners use OSNs to talk to one another about their studies, this circumstance not only encourages them but also reminds them that they should be studying, which in turn increases their motivation as well as the degree of commitment to their studies. 
The three remaining factors are all linked to OSN weaknesses concerning studies. The variance explained by them is not too high: $8 \%, 7 \%$, and $6 \%$ respectively. The fifth factor is called Anxiety, because it stresses how anxious students may feel if they cannot check their OSNs for a long time. The existence of information on those networks that they do not know about has the same effect on them.

The sixth factor was labelled as Privacy, since it contained items such as: "I prefer not to be on OSNs for privacy issues", and "I don't like to disclose private information on OSNs".

Finally, the seventh factor —Multitasking — contained two items as well: "Using OSNs while studying reduces my concentration"; and "work and study are incompatible with OSNs".

\subsection{Typology: Cluster Analysis}

All seven factors obtained in the preceding analysis subsequently served to carry out a classification based on the cluster analysis method, which permitted to obtain a typology of students according to their views about OSNs in general and, more specifically, about how they influenced students' academic performance. Following previous studies devoted to cluster formulation (Malhotra, Gosain \& El Sawy, 2005), this cluster analysis developed in two steps: the hierarchical cluster method was firstly applied to determine the number of clusters which had to be extracted, after which the non-hierarchical cluster made it possible to define the characteristics of those clusters.

A hierarchical conglomerate analysis performed with the seven factors mentioned above using Ward's method showed that obtaining three conglomerates seemed pertinent, since the biggest difference between coefficient changes in percentage terms appeared with three groups. This was followed by a non-hierarchical conglomerate analysis where the K-means method was applied to the aforesaid factors, validating the results obtained by means of an ANOVA 
analysis, and confirming that the latter is appropriate because all the variables included are significant. ${ }^{1}$

The three resulting clusters had 12 students interviewed in the first group, 14 in the second one, and 33 in the third. Each one of these groups was interpreted to identify the differences existing between them. Table 6 offers the equality of means test for groups with respect to the factors comprised in them.

The first cluster was termed as Worried and anxious, since Table 6 unmistakably shows it as being made up of two negative factors related to the time that social networks take away from students, and to the addiction that such networks generate in them, as well as to the attention deficit and anxiety that students suffer from when they cannot check their OSNs.

The second cluster — Balanced — included 14 students and gathered both negative and positive factors regarding OSNs. Examples of positive factors are collaboration, friendship, and trust; privacy and multitasking stand out among the negative ones. Students belonging to this cluster would thus score higher in the aforementioned positive factors and in the negative ones alike. Caution once again becomes a must in this second cluster when assessing the factor related to friendship and trust, which shows a low significance level.

As for the third cluster — the most numerous one with 33 students - it was called Motivated and committed, since it brought together the students with higher scores in this respect.

\footnotetext{
${ }^{1}$ Except for the factor referring to friendship and trust, which is not significant.
}

\begin{tabular}{|l|r|r|}
\hline Variable (Factor) & F & Sign. \\
\hline Time, addition, attention deficit & 5.024 & 0.010 \\
Collaboration & 7.910 & 0.001 \\
Friendship and trust & 1.272 & 0.288 \\
Motivation and commitment & 2.605 & 0.083 \\
Anxiety & 13.021 & 0.000 \\
Privacy & 4.440 & 0.016 \\
Multitasking & 5.529 & 0.006 \\
\hline
\end{tabular}


Last but not least, a Chi-square analysis helped verify the potential identification of the clusters obtained with the characteristics linked to the profile of the students interviewed. The only relationship found was with the number of networks used by students. Whereas those using fewer networks did not identify with any specific cluster, those who used more than three networks simultaneously usually belonged to the third cluster of students, formed by those most highly motivated and committed in their studies thanks to OSN use (Chi-square 6.909, signification 0.032). No significant relationship emerged between students' membership in a specific cluster and their age or gender, though (see Table 7).

INSERT TABLE 7

\section{Discussion and Conclusions}

Digital education is becoming increasingly influential both in distance teaching and in the classroom, which definitely paves the way for new learning and teaching models (Sousa et al., 2018). The impact of technology on students' results is a study area that needs to be addressed not only by researchers in Information Systems but also by those working in Management, since these instruments commonly appear as a teaching tool in the subjects related to this field (Hwang, 2018). Therefore, this work is clearly relevant.

The literature review permitted to identify the strengths and weaknesses of OSNs when it comes to the extent to which they determine academic performance. An initial analysis led to conclude that students assign more importance to strengths than to weaknesses, i.e. the positive influences of OSNs outnumber the negative ones in their opinion.

Carrying out a factor analysis resulted in obtaining seven factors associated with the aforementioned strengths and weaknesses. It follows from those factors that students are above all concerned because OSNs might cause them problems related to time waste and attention deficit, and even make them eventually develop different degrees of addiction. This had already 
been confirmed by previous studies (Mendoza et al., 2018; Kirschner \& Karpinski, 2010; Paul, Baker \& Cochram, 2012; Zaremohzzabieh et al., 2014). Positive factors related to such networks, including improved collaboration (highlighted in the study of Jaffar (2014)), the strengthening of friendship- and trust-based ties with classmates (stressed in the papers written by Evans et al. (2016) and Chang \& Lee (2013)), as well as motivation and commitment to studies (previously analyzed by Aubry (2013), Haylett (2016), Jaffar (2014) and Junco (2012a)), are all highly valued. Therefore, in tune with the findings of previous research works (Gonzalez, Gasco \& Llopis, 2016), a positive result in favor of OSNs and their relationship with academic performance comes out of this study.

A cluster analysis helped obtain three groups of students according to their views about OSNs and about their impact on academic performance. The smallest group, referred to as worried and anxious, brought together the students with mostly negative opinions about OSNs. As for the group of balanced students, who assessed both the strengths and the weaknesses of OSNs, it was neither the most numerous nor the smallest one. Finally, the group with the largest number of students had a favorable opinion about the effects derived from using these networks. For this reason, they were labelled as motivated and committed students. This result once again confirms that most students show positive attitudes toward OSNs, prioritizing positive impacts over negative ones. Nevertheless, lecturers should warn this large group of learners that, in addition to the advantages that social networks can bring for their academic results, these networks also entail significant risks. Students will definitely need to be reminded of the need to keep control over technology at all times to fend off such risks (Berger, Wyss \& Knoch, 2018).

Lecturers should know this typology, since the diverse groups of students require different orientation patterns regarding OSN use. Finally, the examination of student profiles along with their membership in the three groups derived from the cluster analysis performed led to the 
conclusion that the most motivated and committed students, or expressed differently, those more in favor of using OSNs, are also the ones who use a higher number of networks. Researchers should continue analyzing the typology proposed. By way of example, future research works might as well check whether using a larger number of networks makes students develop a more favorable attitude toward them, or conversely, if it is their positive opinion about using networks that encourages them to use a wider range of networks.

As for limitations, it must be highlighted that this paper is based on students' opinions, and not on objective data about their performance which could result from their marks, for example. Other studies dedicated to the same topic (Aladwani \& Almarzouq, 2016) also took students' opinions as their reference, though —not surprisingly, since these opinions are extremely important. After all, students will be the main users of these technologies, not only in their current role as students but also in their future as professionals or executives. Understanding their perspective thus becomes essential to establish patterns able to improve the integration of these technologies into teaching and learning methodologies, as well as into work routines.

Despite the representativeness of the response rate obtained, note that the students under study are enrolled in a specific subject taught at a specific university, which means that extrapolating the conclusions of this study to all university students, in different types of degrees and a variety of countries, would entail some risks.

In any case, all these findings should provide food for thought, especially to teachers. The advantages that these technologies bring to teaching and learning can hardly be denied, especially in the light of their widespread acceptance among students.

\section{References}

Aladwani, A.M. \& Almarzouq, M. (2016). Understanding compulsive social media use: The premise of complementing self-conceptions mismatch with technology. Computers in Human Behavior. 60, 575-581.

Alloway T.P., Horton, J., Alloway, R.G. \& Dawson, C. (2013). Social networking sites and cognitive abilities: Do they make you smarter? Computers \& Education. 63, 10-16. 
Al-Rahmi, W.M., Othman, M.S. \& Musa, M.A. (2014). The Improvement of Students' Academic Performance by Using Social Media through Collaborative Learning in Malaysian Higher Education. Asian Social Science. 10(8), 210-221.

Aubry, J. (2013). Facebook-Induced Motivation Shifts in a French Online Course. TechTrends. 57(6), 81-87.

Bartlett, M. S. (1950). Tests of significance in factor analysis. British Journal of Statistical Psychology. 3(2), 77-85.

Berger, S., Wyss, A. M., \& Knoch, D. (2018). Low self-control capacity is associated with immediate responses to smartphone signals. Computers in Human Behavior. 86, 45-51.

Cain, J. \& Policastri, A. (2011). Instructional design and assessment. Using Facebook as an informal learning environment. American Journal of Pharmaceutical Education. 75 (10). Article 207.

Chang, W-L. \& Lee, C-Y. (2013). Trust as a Learning Facilitator that Affects Students' Learning Performance in the Facebook Community: An Investigation in a Business Planning Writing Course. Computers \& Education. 62, 320-327.

Duncan, D.G. \& Barczyk, C.C. (2013). Facebook in the University Classroom: Do Students Perceive that it Enhances Community of Practice and Sense of Community? International Journal of Business and Social Science. 4(3), 1-14.

Evans, E. D., McFarland, D. A., Rios-Aguilar, C., \& Deil-Amen, R. (2016). Community (in) Colleges: The Relationship Between Online Network Involvement and Academic Outcomes at a Community College. Community College Review. 44(3), 232-254.

Gneiser, M., Heidemann, J., Klier, M., Landherr, A. \& Probst, F. (2012), Valuation of online social networks taking into account users' interconnectedness. Information Systems and E-Business Management. 10(1), pp. 61-84.

George, D.R., Dellasega, C.; Whitehead, M.M. \& Bordon, A. (2013). Facebook-based stress management resources for first-year medical students: A multi-method evaluation. Computers in Human Behavior. 29(3), 559-562.

Gonzalez, R.; Gasco, J. \& Llopis, J. (2015). Facebook in teaching: strengths and weaknesses. International Journal of Information and Learning Technology. 32(1), 65-78.

Gonzalez, M. R.; Gasco, J. L. \& Llopis, J. (2016). Facebook and Academic Performance: A Positive Outcome. The Anthropologist. 23 (1-2), 59-67.

Goodband, J.H., Solomon, Y., Samuels, P.C., Lawson, D. \& Bhakta, R. (2012). Limits and potentials of social networking in academia: Case study of the evolution of a mathematics Facebook community. Learning, Media and Technology. 37(3), 236-252.

Hwang, A. (2018). Online and Hybrid Learning. Journal of Management Education. 42(2), 557-563.

Haylett, C. (2016). Use of Social Media for Teaching Online Courses and Enhancing Business Communication Skills at the University Level: Can This Really Be Done? International Journal of Online Pedagogy and Course Design (IJOPCD). 6(4), 71-85.

Helm, C. (2017). Effects of social learning networks on student academic achievement and prosocial behavior in accounting. Journal for Educational Research Online. 9(1), 52-76.

Hew, K.F. (2011). Students' and teachers' use of Facebook. Computers in Human Behavior. 27(2), 662-676.

$\mathrm{Hu}$, Y-Ch. (2006). Genetic Algorithm in Designing Fuzzy Information Retrieval-Based Classifier by Principal Component Analysis. Computers \& Industrial Engineering. 51(1), 117-127.

Huang, H.T.D. \& Hung S.T. (2013). Exploring the utility of a video-based online EFL discussion forum. British Journal of Educational Technology. 44(3), E-90-E94.

Jaffar, A.A. (2014). Exploring the use of a Facebook page in anatomy education. Anatomical Sciences Education. 7(3), 199-208. 
Judd, T. (2014). Making sense of multitasking: The role of Facebook. Computers \& Education. 70, 194-202.

Junco, R. (2012a). Too much face and not enough books: The relationship between multiple indices of Facebook use and academic performance. Computers in Human Behavior. 28(1), 187-198.

Junco, R. (2012b). In-class multitasking and academic performance. Computers in Human Behavior. 28(6), 2236-2243.

Kalpidou, M., Costin, D. \& Morris, J. (2011). The relationship between Facebook and the wellbeing of undergraduate college students. Cyberpsychology, Behavior, and Social Networking. 14(4), 183-189.

Kaur, S., Ganapathy, M. \& Sidhu, G.K. (2012). Designing Learning Elements Using the Multiliteracies Approach in an ESL Writing Classroom. The Southeast Asian Journal of English Language Studies. 18(3), 119-134.

Kirschner, P.A. \& Karpinski, A.C. (2010). Facebook and academic performance. Computers in Human Behavior. 26(6), 1237-1245.

Lampe, C.; Wohn, D.Y.; Vitak, J.; Ellison, N.B. \& Wash, R. (2011). Student use of Facebook for organizing collaborative classroom activities. Computer-Supported Collaborative Learning. 6(3), 329-347.

Lateh, A. (2014). Integrating Facebook social network for the statistics course: Its outcomes of undergraduate students' Prince of Songkla University Pattani Campus. Asian Social Science. 10(6), 212-219

Lee, E.B. (2014). Facebook use and texting among African American and Hispanic teenagers: An implication for academic performance. Journal of Black Studies. 45(2), 83-101.

Magen-Nagar, N., \& Shonfeld, M. (2018). The impact of an online collaborative learning program on students' attitude toward technology. Interactive Learning Environments. 26(5), 621-637.

Malhotra, A., Gosain, S. \& El Sawy, O. (2005). Absorptive Capacity Configurations in Supply Chains: Gearing for Partner-Enabled Market Knowledge Creation. MIS Quarterly. 29 (1), 145-187.

Manca, S. \& Ranieri, M. (2013). Is it a tool suitable for learning? A critical review of the literature on Facebook as a technology-enhanced learning environment. Journal of Computer Assisted Learning. 29(6), 487-504.

Mendoza, J. S., Pody, B. C., Lee, S., Kim, M., \& McDonough, I. M. (2018). The effect of cellphones on attention and learning: The influences of time, distraction, and nomophobia. Computers in Human Behavior. 86, 52-60.

Morley, D.A. (2014). Supporting student nurses in practice with additional online communication tools. Nurse Education in Practice. 14(1), 69-75.

Paul, J.A., Baker, H.M. \& Cochran, J.D. (2012). Effect of online social networking on student academic performance. Computers in Human Behavior. 28(6), 2117-2127.

Rouis, S. (2012). Impact of cognitive absorption on Facebook on students' achievement. Cyberpsychology, Behavior, and Social Networking. 15(6), 296-303.

Rouis, S., Limayem, M. \& Salehi-Sangari, E. (2011). Impact of Facebook usage on students' academic achievement: Role of self-regulation and trust. Electronic Journal of Research in Educational Psychology. 9(3), 961-994.

Siegle, D. (2011). Facing Facebook: A Guide for Nonteens. Gifted Child Today. 34(2), 14-19.

Sousa, M.J., Carmo, M., Gonçalves, A.C., Cruz, R. \& Martins, J.M. (2018). Creating knowledge and entrepreneurial capacity for $\mathrm{HE}$ students with digital education methodologies: Differences in the perceptions of students and entrepreneurs. Journal of Business Research. In press. https://doi.org/10.1016/j.jbusres.2018.02.005 
Suwannatthachote, P. \& Tantrarungroj, P. (2012). How Facebook Connects Students' Group Work Collaboration: A Relationship between Personal Facebook Usage and Group Engagement. Creative Education. 3, 15-19.

Taylor, S.A.; Mulligan, J.R. \& Ishida, Ch. (2012). Facebook, Social Networking, and Business Education. American Journal of Business Education. 5(4), 437-447.

Tower, M., Latimer, S. \& Hewitt, J. (2014). Social networking as a learning tool: Nursing students' perception of efficacy. Nurse Education Today. 34(6), 1012-1017.

Wang, J. (2013). What higher educational professionals need to know about today's students: online social networks. TOJET: The Turkish Online Journal of Educational Technology. 12(3), 180-193.

Wohn, D.Y. \& LaRose, R. (2014). Effects of loneliness and differential usage of Facebook on college adjustment of first-year students. Computers \& Education. 76, 158-167.

Zaremohzzabieh, Z., Samah, B.A., Omar, S.Z., Bolong, J. \& Kamarudin, N.A. (2014). Addictive Facebook Use among University Students. Asian Social Science. 10(6), $107-$ 116. 
Table 1: Literature Review: students and OSNs

\begin{tabular}{|c|c|}
\hline AUTHOR & Contribution \\
\hline $\begin{array}{l}\text { Aladwani \& } \\
\text { Almarzouq (2016) }\end{array}$ & $\begin{array}{l}\text { Universities must obtain advantages derived from using OSNs in the academic context but, at } \\
\text { the same time, they should be vigilant about their possible negative effects on students, } \\
\text { associated with their excessive and compulsive use. Students with a lower self-esteem level } \\
\text { are the most prone to using these networks compulsively, which in turn usually leads to poor } \\
\text { academic results. }\end{array}$ \\
\hline $\begin{array}{l}\text { Alloway, Horton, } \\
\text { Alloway \& } \\
\text { Dawson (2013) }\end{array}$ & $\begin{array}{l}\text { OSN use generates a social climate from which students can benefit. It improves their } \\
\text { cognitive skills, along with aspects related to academic achievement, such as verbal skills. }\end{array}$ \\
\hline $\begin{array}{l}\text { Al-Rahmi, } \\
\text { Othman \& Musa } \\
\text { (2014) }\end{array}$ & $\begin{array}{l}\text { OSNs facilitate academic experience and collaborative learning with most participants. Those } \\
\text { students who interact with their classmates and teachers, and are committed to their lessons, } \\
\text { achieve a collaborative learning, which in turn allows them to improve their degree of } \\
\text { satisfaction as well as their academic performance thanks to OSN use. }\end{array}$ \\
\hline Aubry (2013) & $\begin{array}{l}\text { Using Facebook as a tool for students to communicate with their teachers may replace other } \\
\text { interaction forms, and implies a greater intrinsic motivation for students. }\end{array}$ \\
\hline $\begin{array}{l}\text { Chang \& Lee } \\
\text { (2013) }\end{array}$ & Trust is a facilitator which affects the results of students belonging to a Facebook community. \\
\hline $\begin{array}{l}\text { Duncan \& Barzyk } \\
\text { (2013) }\end{array}$ & $\begin{array}{l}\text { Students perceive that OSN use improves their sense of social learning, together with their } \\
\text { sense of connectivity. Students have the impression that Facebook makes it easier to create } \\
\text { a community of practice, since it facilitates knowledge sharing. }\end{array}$ \\
\hline $\begin{array}{l}\text { Evans, } \\
\text { McFarland, Rios- } \\
\text { Aguilar \& Deil- } \\
\text { Amen (2016) }\end{array}$ & $\begin{array}{l}\text { Students can academically benefit from connections through OSNs with their partners who } \\
\text { outperform them. This is why an effort must be made by academic managers to forge } \\
\text { friendship ties between students. To which must be added that social networks, increasingly } \\
\text { focused on socio-economic integration, have the capacity to become a cheap means through } \\
\text { which academic managers will be able to help their students, and to improve their academic } \\
\text { level. }\end{array}$ \\
\hline $\begin{array}{l}\text { George, } \\
\text { Dellasega, } \\
\text { Whitehead \& } \\
\text { Bordon (2013) }\end{array}$ & $\begin{array}{l}\text { Facebook can prove useful as a tool to provide support between students, and it has the } \\
\text { potential to contain resources thanks to which freshmen (first-year students) will find it easier } \\
\text { to handle stress. }\end{array}$ \\
\hline $\begin{array}{l}\text { Gonzalez, Gasco } \\
\& \text { Llopis (2015) }\end{array}$ & $\begin{array}{l}\text { It follows from the results obtained in a survey among university students that Facebook is } \\
\text { likely to have a positive impact on students' performance. Students are satisfied with the use } \\
\text { of Facebook for academic purposes. The students who show a more negative attitude toward } \\
\text { Facebook are the ones who have never used this social network. }\end{array}$ \\
\hline $\begin{array}{l}\text { Gonzalez, Gasco } \\
\text { \& Llopis (2016) }\end{array}$ & $\begin{array}{l}\text { Analyzing the literature on Facebook and its impact on academic performance leads to } \\
\text { conclude that Facebook's positive influence on academic results overshadows its negative } \\
\text { influence. }\end{array}$ \\
\hline $\begin{array}{l}\text { Goodband et al. } \\
\text { (2012) }\end{array}$ & $\begin{array}{l}\text { Facebook helps students not only to communicate with one another but also to reinforce their } \\
\text { pre-existing friendship ties. }\end{array}$ \\
\hline Haylett (2016) & $\begin{array}{l}\text { Examining the literature about the use of OSNs for online teaching, its advantages and } \\
\text { drawbacks, leads to draw the conclusion that irrefutable evidence exists suggesting that the } \\
\text { use of social media for online teaching positively correlates with students' commitment. } \\
\text { Instead, a negative correlation exists with students' achievement. }\end{array}$ \\
\hline Hew (2011) & $\begin{array}{l}\text { There are multiple reasons to use Facebook, but the most important one among students is } \\
\text { the chance to maintain relationships with people they know. Even though students using } \\
\text { Facebook spend fewer hours studying than those who do not have that network, one cannot } \\
\text { infer a direct link between Facebook use and academic performance. Students see Facebook } \\
\text { as a tool to have fun, not to be used for serious matters. }\end{array}$ \\
\hline $\begin{array}{l}\text { Huang \& Hung } \\
\text { (2013) }\end{array}$ & $\begin{array}{l}\text { Using online forums related to languages may serve to strengthen relationships between study } \\
\text { partners, and it improves the opportunities to carry out written as well as oral practice, } \\
\text { cultivating the skills associated with speaking in public. }\end{array}$ \\
\hline Jaffar (2014) & $\begin{array}{l}\text { The use of Facebook as a teaching instrument not only favors students' commitment and } \\
\text { motivation but also enhances collaboration and peer assessment. It is an innovative way to } \\
\text { bring teaching materials closer to students. }\end{array}$ \\
\hline Judd (2014) & $\begin{array}{l}\text { Regardless of whether using Facebook on a regular basis constitutes a cause or a symptom } \\
\text { of multitasking, Facebook use seems to be associated with high multitasking levels, which } \\
\text { reduces students' work effectiveness. }\end{array}$ \\
\hline
\end{tabular}




\begin{tabular}{|c|c|}
\hline Junco (2012a) & $\begin{array}{l}\text { The time used on Facebook negatively correlates with students' results. Nevertheless, a } \\
\text { distinction should be drawn: when OSNs are utilized to share or collect information, that use } \\
\text { is directly related to students' commitment. If networks are used to socialize or for non- } \\
\text { communicative activities (e.g. playing or watching what others have done), such uses } \\
\text { negatively correlate with commitment. }\end{array}$ \\
\hline Junco (2012b) & $\begin{array}{l}\text { Those students who want to do several tasks at a time, such as using OSNs and studying } \\
\text { simultaneously, have worse academic results in the long term. }\end{array}$ \\
\hline $\begin{array}{l}\text { Kalpidou, Costin } \\
\text { \& Morris (2011) }\end{array}$ & $\begin{array}{l}\text { Spending plenty of time on Facebook relates to students' low self-esteem. The number of } \\
\text { Facebook friends negatively correlates with emotional and academic adjustment among first- } \\
\text { year students. Instead, it is positively associated with social adjustment and the affection for } \\
\text { the institution among students enrolled in the last years of university. }\end{array}$ \\
\hline $\begin{array}{l}\text { Kirschner \& } \\
\text { Karpinski (2010) }\end{array}$ & $\begin{array}{l}\text { On average, Facebook users show lower academic performances than non-users. Such users } \\
\text { are usually more involved in non-academic activities, which suggests a higher degree of social } \\
\text { extroversion. However, Facebook users said that its use did not influence their academic } \\
\text { results, and added that academic activities constituted a priority for them. Those admitting that } \\
\text { it could have a somewhat negative impact mentioned procrastination - linked to bad time } \\
\text { management. }\end{array}$ \\
\hline Lateh (2014) & $\begin{array}{l}\text { Even though using Facebook as a teaching tool makes student interaction increase, no } \\
\text { significant differences in results exist between students who use Facebook and those who do } \\
\text { not use that network. }\end{array}$ \\
\hline $\begin{array}{l}\text { Manca } \\
(2013)\end{array}$ & $\begin{array}{l}\text { Despite the claims that the new generations of students badly need technological change, and } \\
\text { that they have great expectations about the use of technology as a teaching means, students } \\
\text { not always feel at ease with technologies such as Facebook. Furthermore, they are apparently } \\
\text { not willing to use informal instruments (e.g. OSNs) as their only learning tool. }\end{array}$ \\
\hline Morle & $\begin{array}{l}\text { and learning. A great risk is assumed } \\
\text { e of OSNs as an essential part of the }\end{array}$ \\
\hline $\begin{array}{l}\text { Paul } \\
\text { Cocl }\end{array}$ & $\begin{array}{l}\text { id academic performance. Academic } \\
\text { y manage their time, since a positive } \\
\text { e spent on social networks. }\end{array}$ \\
\hline Rouis & $\begin{array}{l}\text { The time used on Facebook does not significantly affect academic results, which is why no } \\
\text { restrictions need to be imposed on students. Much more attention must be paid to students' } \\
\text { interest in their studies - and to the ability to perform various tasks, as well as to manage their } \\
\text { concentration skills and priorities- when analyzing such results. }\end{array}$ \\
\hline $\begin{array}{l}\text { Rouis, } \\
\text { Salehi- } \\
\text { (2011) }\end{array}$ & $\begin{array}{l}\text { An extensive use of Facebook by students with extrovert personalities leads to worse } \\
\text { academic performances. Instead, students with a higher self-regulation can better control their } \\
\text { presence on these platforms. }\end{array}$ \\
\hline $\begin{array}{l}\text { Taylc } \\
\text { Ishid }\end{array}$ & $\begin{array}{l}\text { Students are reluctant to utilize OSNs for academic purposes, mainly due to problems linked } \\
\text { to the boundaries between the private and the public sphere, and to the privacy issue. } \\
\text { Teachers should not be discouraged from using OSNs, though; they simply need to be aware } \\
\text { of matters referring to limits and students' privacy. }\end{array}$ \\
\hline $\begin{array}{l}\text { Tow } \\
\text { Hew }\end{array}$ & $\begin{array}{l}\text { OSNs represent an innovative method with which academics can involve and attract students } \\
\text { in their learning. They promote academic interaction between students, and constitute an } \\
\text { environment and support which makes peer-to-peer learning and teaching easier. This } \\
\text { encourages students to work together, developing their capacity for critical reflection. }\end{array}$ \\
\hline $\mathrm{Wa}$ & $\begin{array}{l}\text { Students use Facebook in a way that may turn out to be positive or negative for their academic } \\
\text { results, and for their commitment to the studies they are enrolled in. By way of example, } \\
\text { students can obtain advantages from its communication-related characteristics. It can prove } \\
\text { motivating because participants express their emotions, and shy students dare to ask and } \\
\text { intervene to a greater extent than they do in face-to-face classes. The possibility also exists } \\
\text { to create a commitment and a sense of belonging, both within the group and within the } \\
\text { institution. }\end{array}$ \\
\hline $\begin{array}{l}\text { Wohn \& } \\
(2014)\end{array}$ & $\begin{array}{l}\text { Despite all the bad "press" about Facebook's negative impact on academic performance, its } \\
\text { effects are negligible. }\end{array}$ \\
\hline $\begin{array}{l}\text { Zaremohzzabieh } \\
\text { et al (2014) }\end{array}$ & $\begin{array}{l}\text { Students may develop an addiction to OSNs such as Facebook, and three potential problems } \\
\text { arise: the compulsive use of networks; the high frequency of use; and their use to avoid other } \\
\text { types of activities and responsibilities. }\end{array}$ \\
\hline
\end{tabular}


Table 2: Measures for constructs and reliability

\begin{tabular}{|c|c|c|c|}
\hline Construct & Source & Measure & $\begin{array}{c}\text { Reliability } \\
\text { (Cronbach's } \alpha)\end{array}$ \\
\hline OSN Weaknesses & $\begin{array}{c}\text { Literature review, especially } \\
\text { Gonzalez, Gasco \& Llopis } \\
(2015)\end{array}$ & 12 items, 1-5 Likert scale & $\begin{array}{c}0.797 \\
\text { Acceptable/Good }\end{array}$ \\
\hline OSN Strengths & $\begin{array}{c}\text { Literature review, especially } \\
\text { Gonzalez, Gasco \& Llopis } \\
(2015)\end{array}$ & 11 items, 1-5 Likert scale & 0.803 Good \\
\hline
\end{tabular}

Table 3: Interviewed students' profile, and networks that they use

\begin{tabular}{|c|r|r|}
\hline & $\mathrm{N}$. & $\%$ \\
\hline Gender & Female 51 & 60.7 \\
& Male 33 & 39.3 \\
\hline Age & 22.9 (mean) & \\
\hline No. of OSNs used & 3.6 (mean) & \\
\hline \multirow{5}{*}{ OSN Used } & Facebook 64 & 76.2 \\
\cline { 2 - 3 } & YouTube 62 & 73.8 \\
\cline { 2 - 3 } & Instagram 52 & 61.9 \\
\cline { 2 - 3 } & Twitter 24 & 28.6 \\
\cline { 2 - 3 } & Linkedln 11 & 13.1 \\
\cline { 2 - 3 } & Pinterest 7 & 8.3 \\
\cline { 2 - 3 } & Snapchat 4 & 4.8 \\
\cline { 2 - 3 } & Blog 2 & 2.4 \\
\hline
\end{tabular}


Table 4: OSN Weaknesses and Strengths

\begin{tabular}{|c|c|c|c|}
\hline \multicolumn{4}{|l|}{ WEAKNESSES } \\
\hline ITEMS & Mean & Median & Mode \\
\hline Using OSNs reduces my concentration & 4.243 & 5 & 5 \\
\hline Using OSNs takes time away from me & 3.825 & 4 & 5 \\
\hline Using OSNs decreases my attention & 3.456 & 4 & 5 \\
\hline I need to control my use of OSNs so as not to waste time & 3.378 & 4 & 4 \\
\hline Work and study are incompatible with OSNs & 3.123 & 3 & 3 \\
\hline The more I use OSNs, the more I become addicted to them & 3.062 & 3 & 5 \\
\hline I do not like to disclose private information on OSNs & 3.060 & 3 & 3 \\
\hline I must control myself in OSNs & 2.951 & 3 & 1 \\
\hline I cannot concentrate because of OSNs & 2.493 & 2 & 2 \\
\hline I prefer not to be on OSNs for privacy issues & 2.271 & 2 & 1 \\
\hline Not checking OSNs for a long time makes me anxious & 1.831 & 2 & 1 \\
\hline Being unaware of information from my OSNs makes me anxious & 1.662 & 1 & 1 \\
\hline \multicolumn{4}{|l|}{ STRENGTHS } \\
\hline Teamwork is easier with OSNs & 4.095 & 4 & 5 \\
\hline I like my classmates to communicate with me via OSNs & 3.928 & 4 & 5 \\
\hline $\begin{array}{l}\text { Using OSNs with partners and teachers improves my satisfaction with } \\
\text { studies }\end{array}$ & 3.702 & 4 & 4 \\
\hline Using OSNs helps me share study contents & 3.702 & 4 & 4 \\
\hline I have reinforced my friendship ties with partners thanks to OSNs & 3.583 & 4 & 4 \\
\hline $\begin{array}{l}\text { Exchanging comments with classmates through OSNs encourages me to } \\
\text { study }\end{array}$ & 3.253 & 3 & 4 \\
\hline $\begin{array}{l}\text { Communicating with my classmates through OSNs provides me with } \\
\text { motivation to study }\end{array}$ & 3.097 & 3 & 3 \\
\hline $\begin{array}{l}\text { Communicating with my partners via OSNs has improved my integration into } \\
\text { the classroom }\end{array}$ & 3.097 & 3 & 4 \\
\hline I trust more partners with whom I keep in touch through OSNs & 3.051 & 3 & 4 \\
\hline Using OSNs improves collaboration & 3.047 & 3 & 3 \\
\hline Using OSNs with peers reminds me that I must study & 2.839 & 3 & 4 \\
\hline
\end{tabular}


Table 5: Factor Analysis. Total Variance Explained and Rotated Factor Matrix

\begin{tabular}{|c|c|c|c|c|c|c|c|c|c|c|c|c|c|c|}
\hline & \multicolumn{3}{|c|}{ Initial Eigenvalues } & \multicolumn{3}{|c|}{$\begin{array}{l}\text { Rotation Sum of Squared } \\
\text { Loadings }\end{array}$} & \multicolumn{8}{|c|}{ Rotated Factor Matrix } \\
\hline$\stackrel{\Xi}{\Phi}$ & $\begin{array}{l}\overline{\widetilde{\pi}} \\
\stackrel{0}{\circ}\end{array}$ & 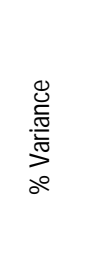 & 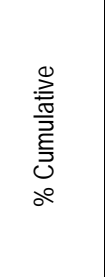 & $\begin{array}{l}\overline{\widetilde{\pi}} \\
\text { 음 }\end{array}$ & 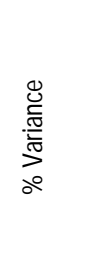 & 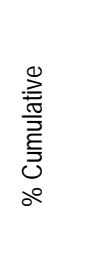 & & 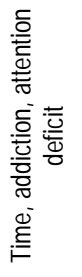 & 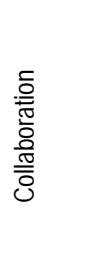 & 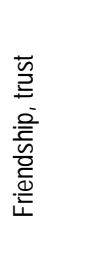 & 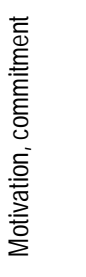 & $\frac{\sqrt{0}}{\frac{2}{x}}$ & 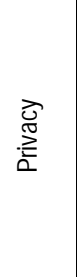 & 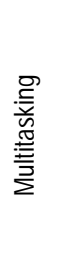 \\
\hline 1 & 4.948 & 21.511 & 21.511 & 4.400 & 19.130 & 19.130 & It improves collaboration & -.340 & .399 & .395 & .078 & .081 & -.066 & .119 \\
\hline 2 & 4.015 & 17.456 & 38.967 & 2.530 & 11.001 & 30.130 & Teamwork & -.195 & .755 & .257 & .188 & -.101 & -.022 & -.115 \\
\hline 3 & 2.139 & 9.300 & 48.268 & 2.313 & 10.058 & 40.188 & Sharing contents & .049 & 621 & .013 & .200 & .073 & -.310 & -.177 \\
\hline 4 & 1.613 & 7.013 & 55.281 & 2.274 & 9.887 & 50.075 & It improves satisfaction & .130 & .823 & -.135 & -.023 & .081 & .048 & .001 \\
\hline 5 & 1.449 & 6.298 & 61.579 & 1.898 & 8.250 & 58.325 & Partners communicate & .113 & .202 & .663 & .066 & .129 & -.094 & -.134 \\
\hline 6 & 1.229 & 5.342 & 66.921 & 1.648 & 7.166 & 65.491 & It reduces concentration & .447 & -.247 & .114 & .108 & .091 & .352 & .542 \\
\hline 7 & 1.075 & 4.675 & 71.596 & 1.404 & 6.104 & 71.596 & Work/Study incompatibility & .035 & -.043 & -.151 & -.037 & -.056 & -.062 & .873 \\
\hline 8 & .978 & 4.254 & 75.850 & & & & It takes away time & .722 & -.132 & .099 & .011 & .076 & .130 & .410 \\
\hline 9 & .792 & 3.445 & 79.295 & & & & It is a waste of time & .769 & .037 & -.258 & .070 & .123 & -.139 & .133 \\
\hline 10 & .725 & 3.154 & 82.448 & & & & It motivates me to study & .020 & .430 & .167 & .559 & .280 & -.116 & .042 \\
\hline 11 & .586 & 2.550 & 84.998 & & & & It reminds me to study & .018 & -.061 & .073 & .893 & .038 & .008 & -.032 \\
\hline 12 & .561 & 2.438 & 87.436 & & & & It encourages me to study & -.002 & .415 & .108 & .761 & .046 & -.126 & .019 \\
\hline 13 & .506 & 2.198 & 89.634 & & & & It strengthens friendship & .089 & .354 & .602 & .358 & -.256 & .005 & .039 \\
\hline 14 & .419 & 1.823 & 91.457 & & & & It increases Integration & .048 & -.014 & .688 & .350 & -.372 & .164 & -.067 \\
\hline 15 & .372 & 1.616 & 93.073 & & & & I trust my peers & -.003 & -.205 & .774 & -.087 & .111 & -.071 & -.002 \\
\hline 16 & .341 & 1.483 & 94.556 & & & & I need to control myself & .861 & .102 & .050 & -.013 & .145 & -.148 & -.025 \\
\hline 17 & .293 & 1.275 & 95.831 & & & & I become addicted to them & .781 & .121 & .161 & -.265 & .189 & -.085 & .062 \\
\hline 18 & .258 & 1.121 & 96.952 & & & & It reduces my attention & .848 & .049 & .011 & .216 & .055 & .093 & -.039 \\
\hline 19 & .235 & 1.024 & 97.976 & & & & I cannot concentrate & .773 & -.189 & .085 & -.003 & .179 & -.004 & -.071 \\
\hline 20 & .174 & .755 & 98.730 & & & & Being unaware of information makes me anxious & .355 & .020 & .017 & .081 & .806 & .188 & -.070 \\
\hline 21 & .135 & .588 & 99.318 & & & & Not consulting them makes me anxious & .277 & .081 & -.003 & .103 & .879 & -.028 & .028 \\
\hline 22 & .091 & .395 & 99.713 & & & & I am not on them for privacy reasons & -.138 & -.138 & -.038 & -.286 & .012 & .693 & .204 \\
\hline 23 & .066 & .287 & 100.000 & & & & I do not like to disclose private information & -.001 & -.022 & -.061 & .085 & .080 & .870 & -.135 \\
\hline
\end{tabular}


Table 6: Equality of means test of Weaknesses and Strengths, according to cluster membership

\begin{tabular}{|c|c|c|c|c|c|c|}
\hline \multirow[b]{2}{*}{ Variable (Factor) } & & \multirow[b]{2}{*}{ Mean } & \multicolumn{2}{|c|}{ Levene } & \multirow[b]{2}{*}{ Statistic } & \multirow[b]{2}{*}{ Sign. } \\
\hline & & & $\mathrm{F}$ & Sign. & & \\
\hline \multirow{3}{*}{ Time, addiction, attention deficit } & Cluster $1(n=12)$ & 0.465 & \multirow{3}{*}{0.963} & \multirow{3}{*}{0.388} & \multirow{3}{*}{$5.024(1)$} & \multirow{3}{*}{0.010} \\
\hline & Cluster $2(n=14)$ & -0.647 & & & & \\
\hline & Cluster $3(n=33)$ & 0.105 & & & & \\
\hline \multirow{3}{*}{ Collaboration } & Cluster $1(n=12)$ & -0.799 & \multirow{3}{*}{3.345} & \multirow{3}{*}{0.042} & \multirow{3}{*}{$11.092(2)$} & \multirow{3}{*}{0.004} \\
\hline & Cluster $2(n=14)$ & 0.601 & & & & \\
\hline & Cluster $3(n=33)$ & 0.035 & & & & \\
\hline \multirow[t]{3}{*}{ Friendship, trust } & Cluster $1(n=12)$ & 0.171 & \multirow{3}{*}{0.802} & \multirow{3}{*}{0.454} & \multirow{3}{*}{$1.272(1)$} & \multirow{3}{*}{0.288} \\
\hline & Cluster $2(n=14)$ & 0.279 & & & & \\
\hline & Cluster $3(n=33)$ & -0.180 & & & & \\
\hline \multirow[t]{3}{*}{ Motivation, commitment } & Cluster $1(n=12)$ & -0.369 & \multirow{3}{*}{0.738} & \multirow{3}{*}{0.482} & \multirow{3}{*}{$2.605(1)$} & \multirow{3}{*}{0.083} \\
\hline & Cluster $2(n=14)$ & -0.285 & & & & \\
\hline & Cluster $3(n=33)$ & 0.255 & & & & \\
\hline \multirow[t]{3}{*}{ Anxiety } & Cluster $1(n=12)$ & 1.051 & \multirow{3}{*}{9.909} & \multirow{3}{*}{0.000} & \multirow{3}{*}{$12.664(2)$} & \multirow{3}{*}{0.002} \\
\hline & Cluster $2(n=14)$ & 0.027 & & & & \\
\hline & Cluster $3(n=33)$ & -0.393 & & & & \\
\hline \multirow{3}{*}{ Privacy } & Cluster $1(n=12)$ & 0.105 & \multirow{3}{*}{3.409} & \multirow{3}{*}{0.040} & & \\
\hline & Cluster $2(n=14)$ & 0.597 & & & $6.749(2)$ & 0.034 \\
\hline & Cluster $3(n=33)$ & -0.291 & & & & \\
\hline & Cluster $1(n=12)$ & 0.043 & & & & \\
\hline Multitasking & Cluster $2(n=14)$ & 0.680 & 2.719 & 0.075 & $8.642(2)$ & 0.013 \\
\hline & Cluster $3(n=33)$ & -0.304 & & & & \\
\hline
\end{tabular}

(1) ANOVA F statistic, since Levene's test shows that there is homoscedasticity

(2) Kruskal-Wallis test, since Levene's test shows that there is no homoscedasticity

Table 7: Chi-square to test independence

\begin{tabular}{|c|c|c|c|c|c|c|}
\hline & & Cluster 1 & Cluster 2 & Cluster 3 & Chi-square & Sign. \\
\hline Number of OSNs & Up to 3 & $8(38.1 \%)$ & $5(23.8 \%)$ & $8(38.1 \%)$ & 6.909 & 0.032 \\
& More than 3 & $4(10.5 \%)$ & $9(23.7 \%)$ & $25(65.8 \%)$ & & \\
\hline Gender & & & & & 0.142 & 0.932 \\
Age & & & & & 1.884 & 0.390 \\
\hline
\end{tabular}

